\title{
Memlük Devletinde Sultan ve Emîrlerin Hanefîliğe İlgisi
}

\author{
Prof. Dr. Fatih Yahya Ayaz ${ }^{*}$ \\ Arş. Gör. Dr. Fatmanur Alibekiroğlu Eren ${ }^{2}$
}

Gelis tarihi: 14.10 .2019

Kabul tarihi: 04.11.2019

\section{Atıf bilgisi:}

IBAD Sosyal Bilimler Dergisi

Sayı $5 \quad$ Sayfa: 284-296

Yıl: 2019 Dönem: Güz

This article was checked by Turnitin. Similarity Index 15\%

${ }^{1}$ Çukurova Üniversitesi İlahiyat Fakültesi, Türkiye, fvayaz@,cu.edu.tr, ORCID ID 0000-0003-3261-4915

${ }^{2}$ Çukurova Üniversitesi İlahiyat Fakültesi, Türkiye, falibekiroglu@cu.edu.tr ORCID ID 0000- 0001-9629-5736

* Sorumlu yazar
ÖZ

İslâm tarihindeki en büyük Müslüman Türk devletleri arasında kabul edilen Memlükler (1250-1517), Haçlılar ve Moğollara karşı büyük başarıları ve bu sayede İslâm dünyasının hamisi olmaları gibi bazı özellikleri ile tanınmaktadır. Bu devleti öne çıkaran özellikleri arasında ilme ve ulemaya gösterdiği alaka, kurduğu birçok medrese vasıtasıyla Sünnîliğin Mısır ve Suriye'de yerleşmesine yönelik gayretleri de sayılmaktadır. Esasen Eyyûbî Devleti'nin (567-866/1171-1462) kurucusu Salâhaddin Eyyûbî (567-589/1171-1193) ile başlayan bu faaliyetler Memlükler tarafindan daha da ileriye götürülmüş ve yaygınlaştırılmıştır. Şâfîi mezhebine mensup olan Salâhaddin Eyyûbî, iktidarı devraldığı Fâtımîler'in (297-567/9091171) Mısır ve Suriye'de yaygınlaştırmaya çalıştıkları Şîiliğe karşı bir tedbir olarak çok sayıda medrese inşasına öncülük yapmış ve bunların Sünnî öğretiyi yerleştirmesi için gayret etmiş, bu amaca matuf olarak genelde itikatta Eş‘arî olan Şâfiîlere daha fazla ihtimam göstermiştir. Eyyûbiler'in halefi olan Memlükler ise Şâfiîliğin yaygınlaştığı Mısır ve Suriye'de bu mezhebe mensup ulema ve kadıların idarî öncelik ve imtiyazlarına mani olmamakla birlikte Türklerin yaygın olarak kabul ettiği Hanefîliğe büyük önem göstermişlerdir. Daha kuruluş döneminden itibaren başlayan Hanefiliğe ilgi bazı sultan ve emîrlerin gayretleriyle daha da ileri götürülmüş hatta idarede nüfuz sahibi meşhur emîrlerden biri Hanefî mezhebini Şafîiliğin önüne geçirmek amacıyla çeşitli çalışmalar yapmıştır. Yine önde gelen bazı emîrler bu sevgilerini ilmî sahaya taşımış, Hanefî̀ mezhebi üzerine eser yazacak kadar ilmî yetkinliğe ulaşmıştır. Bu çalışmada Hanefî mezhebine bağlı olan bazı Memlük sultan ve emîrlerinin faaliyetleri ve onların bu faaliyetleri neticesinde diğer mezheplere mensup ulema ile yaşadıkları çekişme, tartışma vb. hususlar ele alınmıştır. Öncelikle dört mezhepten birer başkadı tayini meselesine işaret edildikten sonra bu uygulamanın sebepleri ve sonuçları üzerinden Hanefî mezhebinin idaredeki konumunu incelenmiş, daha sonra örnekler vermek suretiyle Hanefilliğe düşkün yöneticilerin bu tavırları yorumlanmıştır. Böylece Türklerin Müslüman olduktan sonra amelde Hanefîliği tercih etmeleri meselesine, ülkemizde pek fazla tanınmayan Türk devleti Memlükler'den bazı örnekler vererek katkıda bulunmak amaçlanmıştır.

Anahtar Kelimeler: Memlükler, Hanefîlik, Şâfiîlik, Hanefî emîrler. 


\title{
On the Interest of Mamluk Sultans and Amirs to the Hanefite in the Mamluk State
}

\author{
Prof. Dr. Fatih Yahya Ayaz ${ }^{*}$ \\ Res. Assist. Dr. Fatmanur Alibekiroğlu Eren ${ }^{2}$
}

First received: 14.10 .2019

Accepted: 04.11.2019

\section{Citation:}

IBAD Journal of Social Sciences

Issue: 5

Pages: 284-296

Year: 2019

Session: Fall

This article was checked by Turnitin. Similarity Index $15 \%$

1 Çukurova University, Turkey, fyayaz@cu.edu.tr,

ORCID ID 0000-0003-3261-4915

2 Çukurova University, Turkey, falibekiroglu@,cu.edu.tr

ORCID ID 0000- 0001-9629-5736

* Corresponding Author

\begin{abstract}
Mamluk State which is accepted one of the greatest Muslim-Turkish states in Islamic history is known by some essential characteristics like great victories against Crusaders and Mongols and being protecting power of Islamic World henceforth. Showing great interest in scholarship and scholars, making efforts to establish and generalize Sunnism by building new madrasahs are also among its characteristics, In fact, these activities started by Salahaddin Ayyûbî are improved and generalized by Mamluks. Salahaddin Ayyûbî, as a Shâfîi, tried to remove Fatımid's Shiite traces in Egpt and Syria by building new Sunni madrasahs and along the same line he took more care of Shâfiîs because they are usually Esh'arî.Mamluks took great care of Hanefite Turks generally adopted, however they continued the prerogatives of Shafiî officials (qâdilqudat, for instance). On the other hand, some Mamluk sultans and amirs because of being fond of Hanefite tried to bring Hanefi officials forward. Some of them wrote also books on Hanefi sect. In this paper, we dealt with the activities of some Mamluk statesman fond of Hanefite and their conflicts and polemics with other sects especially with shafiis. Thus, we tried to make contribution to the topic of "Turks are Hanefi" by giving examples from the hisory of Mamluks.
\end{abstract}

Keywords: Mamluks, Hanefite, Shafiite, Hanefi amirs. 


\section{GíRIŞ}

İslâm tarihindeki en büyük Müslüman Türk devletleri arasında kabul edilen Memlükler (648-923/12501517), alışılmış hanedan usulünün dışındaki idare şekilleri, Haçlılar ve Moğollara karşı büyük başarıları ve bu sayede İ́slâm dünyasının hamisi olmaları gibi bazı özellikleri ile tanınmaktadır. Bu devleti öne çıkaran özellikler arasında ilme ve ulemaya gösterdiği alaka ile kurduğu birçok medrese vasıtasıyla Sünnîliğin Misır ve Suriye'de yerleşmesine yönelik gayretlerinden de bahsedilebilir. Esasen Eyyûbî Devleti'nin (567-866/1171-1462) kurucusu Salâhaddin Eyyûbî (567-589/1171-1193) ile başlayan bu faaliyetler Memlükler tarafından daha da ileriye götürülmüş ve yaygınlaştırılmıştır. Şâfîi mezhebine mensup olan Salâhaddin Eyyûbî, iktidarı devraldığı Fâtımîler'in (297-567/909-1171) Mısır ve Suriye'de yaygınlaştırmaya çalıştıkları Şîiliğe karşı bir tedbir olarak çok sayıda medrese inşasına öncülük yapmıştır. Bunların Sünnî öğretiyi yerleştirmesi için gayret etmiş, bu amaca matuf olarak genelde itikatta Eş‘arî olan Şâfiîlere ve Şâfiî mezhebine daha fazla ihtimam göstermiştir.

Eyyûbiler'in halefi olan Memlükler ise Şâfiîlliğin yaygınlaştı̆̆ Mısır ve Suriye'de bu mezhebe mensup ulema ve kadıların idarî öncelik ve imtiyazlarına mani olmamakla birlikte Türklerin yaygın olarak kabul ettiği Hanefîliğe büyük önem göstermişlerdir. Daha kuruluş döneminden itibaren başlayan Hanefîliğe ilgi bazı sultan ve emîrlerin gayretleriyle daha da ileri götürülmüş hatta idarede nüfuz sahibi meşhur emîrlerden biri Hanefî mezhebini Şafîiliğin önüne geçirmek amacıyla çeşitli çalışmalar yapmıştır. Yine önde gelen bazı emîrler bu sevgilerini ilmî sahaya taşımış, Hanefî mezhebi üzerine eser yazacak kadar ilmî yetkinliğe ulaşmıştır.

Biz bu çalışmada Hanefî mezhebine bağlı olan bazı Memlük sultan ve emîrlerinin faaliyetleri ve onların bu faaliyetleri neticesinde diğer mezheplere mensup ulema ile yaşadıkları çekişme, tartışma vb. hususları ele aldık. Çalışmada öncelikle dört mezhepten birer başkadı tayini meselesine işaret ederek bu uygulamanın sebepleri ve sonuçları üzerinden Hanefî mezhebinin idaredeki konumunu incelenmiş, daha sonra örnekler vermek suretiyle Hanefîliğe düşkün yöneticilerin bu tavırları yorumlanmıştır. Memlükler döneminde Hanefîliğin sultan ve emirler nezdindeki konumunu ele alan müstakil bir çalışma yer almamaktadır. Bu nedenle bizim çalışmamız sultan ve emirlerin mezhebî kimliğini belirleme noktasında oldukça önemlidir. Ayrıca, halkın Şâfiî eğilimlere sahip olduğu Memlükler döneminde devlet yönetiminin Hanefîliğe meylettikleri yönündeki iddiayı da doğrular mahiyettedir. Sultanların Hanefîliğe bireysel ilgilerine rağmen Şâfiîiğin devlet nezdindeki gücünü dönemin şartları ve toplumsal taban sayesinde koruduğunu görmek de önemlidir. Makalenin içeriğinde bazı mutaassıp Şâfiî müelliflerin bir kısım Memlük sultanlarının mezheplerine yönelik tespitlerine de yer verilmiş ve bunların sıhhati hususunda tarih kaynaklarına başvurulmuştur. Dolayısıyla çalışmamızın temel amacı Memlük sultan ve askerî erkânı ile halkın genelinin amelî mezhepleri arasındaki farklılık bağlamında Hanefîlik mezhebine müntesiplik meselesine dikkatleri çekmektir. Böylece Türklerin Müslüman olduktan sonra amelde Hanefîliği tercih etmeleri meselesine ülkemizde pek fazla tanınmayan Türk devleti Memlükler'den bazı örnekler vererek katkıda bulunmaya çalıştık.

\section{Dört Başkadı Tayini ve Hanefîliğin Etkisi Meselesi}

Eyyûbîler'in Şiîliğin etkisi ve izlerini ortadan kaldırmak amacıyla başlattıkları bir Şâfîi kâdilkudât (başkadı) idaresi altında yönetim ve halkın hukukî sorunlarını çözme uygulaması Memlükler tarafından da ilk zamanlarda benimsenmiş ve sürdürülmüştür. Ancak Memlük Devleti'nin dördüncü sultanı olan ve aynı zamanda gerçek manada kurucusu kabul edilen el-Melikü'z-Zâhir Baybars (658-676/1260-1277) bu tek başkadılı sisteme bir son vererek önce başkentte daha sonra başka şehirlerde diğer mezheplerden de birer tane kâdilkudât tayin etmek suretiyle yeni bir uygulama başlatmıştır. Baybars bu yeni uygulamasını tedricen yürürlüğe koymuş, öncelikle Eyyûbîler döneminden beri süregelen adlî sistemin başı olan Şâfiî başkadılığına diğer üç mezhepten birer nâib tayin etmiştir (661/1262) (İbn Abdüzzâhir, 1976, s. 182). Bundan kısa bir süre sonra bahsi geçen üç mezhepten müstakil birer başkadı atamak suretiyle uygulamayı tamamlamıştır (663/1263) (Nüveyrî, 1990, s. 177-122; Yalçın, 2016, s. 39-43).

Birçok araştırmaya konu edilen ve tartışılmaya devam eden Baybars'ın söz konusu uygulamasının gerekçeleri üzerinde durmak gerekir. Baybars'ın muasırı olan veya daha sonra yaşamış tarihçilerin eserlerinde konu ile ilgili farklı gerekçelere rastlanmaktadır. Baybars'ın yakınları arasında bulunan ve 
onun hakkında bir biyografi kaleme almış bulunan meşhur münşilerden İbn Abdüzzâhir (ö. 692/1293), önce nâib daha sonra müstakil başkadı tayini șeklindeki bu uygulamaya gerekçe olarak başkent Kahire'ye çeşitli mezheplere mensup çok sayıda âlim ve insanın göç etmesini gösterir (İbn Abdüzzâhir, 1976, s. 182). Yûnînî (ö. 726/1326), Nüveyrî (ö. 733/1333), Zehebî (ö. 748/1347), İbn Kesîr (ö. 774/1373) gibi Türk Memlükler döneminin (648-784/1250-1382) önde gelen tarihçileri ise bu uygulamayla ilgili olarak farklı bir gerekçeden bahsetmektedirler. Buna göre, tek başkadı olan Şâfiî mezhebinden Taceddin b. bintü'l-Eazz (ö. 665/1267), kendi mezhebinin görüşlerine uygun olmayan kararları uygulamakta mütereddit davranmakta ve bu durum farklı mezheplere mensup davacı ve davalıları rahatsız etmektedir. Bu rahatsızlık Sultan Baybars'ın başkanlık ettiği bir mezâlim oturumunda tekrar gündeme gelmiş, sultanın yakınları arasında bulunan ve Taceddin b. bintü'l-Eazz'den de hoşlanmayan Emîr Cemaleddin Aydoğdu (ö. 664/1266), söz konusu oturumda bu hususu vurgulayıp, başkadıyı eleştirerek her mezhepten birer başkadı tayin edilmesi gerektiğini Baybars'a arz etmiştir. Sultan Baybars da Başkadı Taceddin b. bintü'l-Eazz'in bahsi geçen oturumdaki tavır ve kararlarından rahatsız olduğundan bu tavsiyeyi dikkate almış ve her mezhepten birer başkadı atamak suretiyle yeni bir uygulama başlatmıştır (Yûnînî, 1954-1961, 2, s.324-325; Nüveyrî, 1990, 30, s. 117-122; Zehebî, 1999, s. 21; İbn Kesîr, ts., 13, s. 259). Mutaassıp bir Şâfiî olan Taceddin es-Sübkî (ö. 771/1370) ise daha sonra ele alacağımız gibi bu uygulamayı sert bir şekilde eleştirir ve esas gerekçe olarak Sultan Baybars'ın bir konuyla ilgili Taceddin b. bintü'l-Eazz'i huzura davet etmesi ve onun bu daveti reddetmesini, devamında bir Hanefî nâib edinmesine dair talimatı da uygulamamasını gösterir (Sübkî, 1964, 8, s. 319).

Araştırmacılar ise Sultan Baybars'ın dört mezhepten birer başkadı tayin etmesinin gerekçeleriyle alakalı çeşitli yorumlar yapmaktadırlar. Mesela Escovitz, İbn Abdüzzâhir'in işaret ettiği hususa vurgu yaparak Kahire nüfusunun göçlerle artması neticesinde Şâfiî ağırlıklı olan Kahire'de diğer mezhep mensuplarının da çoğalmaya başladığını, Sultan Baybars'ın da bu yeni durumu dikkate alarak böyle bir uygulamaya karar verdiğini ifade eder (Escovitz, 1982, s. 531). Dolayısıyla Escovitz bu uygulamayı tabii bir gelişim ve ihtiyaçlara yönelik çözüm arayışı olarak görmektedir. Özen de söz konusu uygulamanın ihtiyaca binaen gerçekleştiğini, hukukî meselelerin çözümü için idarenin böyle bir karar almak zorunda kaldığını belirtmektedir (Özen, 2001, s. 79). Nielsen ise Sultan Baybars'ın bu uygulamasını, ileride temas edeceğimiz gerekçelerin yanı sıra Memlükler'in Hanefî mezhebini güçlendirme siyasetinin bir parçası olarak değerlendirmektedir (Nielsen, 1984, s. 176). Onun bu kanaatini destekleyen başka araştırmacılar da bulunmaktadır (Yalçın, 2016, s. 43-44).

Bazı araştırmacıların işaret ettiği (Lahmuddin, 2004, s. 105 vd.; Yalçın, 2016, s. 43-45; Rapoport, 2003, s. 213 vd.) ve bizim de iştirak ettiğimiz değerlendirme ise bu uygulamanın Memlükler'in siyasî-dinî meşruiyet arayışı içerisinde iken bir yandan hâkim mezhebin mevcut konumunu muhafaza etmesine izin vermek bir yandan da kendi idare anlayışlarına ve itikadî tercihlerine daha uygun buldukları Hanefî mezhebini ${ }^{1}$ önemli bir mevkie yükseltmek amacına matuf olduğu şeklindedir. Zira Memlük idarecilerinin yönettiği ve muhatap olduğu halk birçok bakımdan yönetimdekilerden farklıydı ve ağırlıklı olarak Şâfiî mezhebine mensuptu. Bu farklılıklar idareci eliti oluşturan askerî sınıf ile halk arasında derin bir ayrılık oluşturmaktaydı. Bu sebeple yönetici elitin aradaki sorunları gidermek için çözümler geliştirmesi elzemdi. Bu noktada Memlük Devleti'ni oluşturan sınıflara kısaca temas etmenin konunun anlaşılmasını kolaylaştıracağı düşüncesiyle Memlük toplumsal yapısını ele almak yerinde olacaktır.

Memlük toplumu, esas itibariyle devlet idaresindeki önemli mevkileri elinde tutan ve Türk Memlükler döneminde ağırlığını Türklerin oluşturduğu hâkim askerî sınıfla, bunlardan etnik menşe bakımından farklı olan ve çeşitli sosyal tabakalara ayrılan halk kesiminden oluşmaktadır. Bu toplumun içinde yaşamış olan İbn Haldûn da (ö. 808/1406), Memlük toplumu için yaptığı sınıflandırmada bu tarz bir genelleme yapmakta ve Memlük Devleti'nde idare ile halkın etnik bakımdan birbirinden farklı olduğunu vurgulamaktadır (İbn Haldûn, 2001, 1, s. 207; krş. Lane-Poole, 1901, s. 252-253; Âşûr, 1992, s. 16). Yine meşhur Memlük tarihçilerinden Makrîzî de (ö. 845/1441), bu tasnifi daha ayrıntılı bir şekilde ele almaktadır (Makrîzî, 1957, s. 72-73). ${ }^{2}$ Hangi tasnif esas alınırsa alınsın, genel olarak Memlükler dönemindeki Mısır toplumunun, idareye hâkim olan ve geliştirdikleri memlük sistemi sayesinde askerî bir aristokrasi meydana getiren üst yönetici elit ve onların yönetimindeki çeşitli mesleklere ve refah

\footnotetext{
${ }^{1}$ Hanefî mezhebi ve Türkler arasındaki ilişkiler için bkz. Bardakoğlu, 1997, s. 6 vd.; Kutlu, 2011, s. 96-119; Şık, 2015, s. 14-15.

2 Diğer tasnifler ve ayrıntılar için bkz. Âşûr, 1992, s. 15-16; Keleş, 2002, s. 394.
} 
seviyesine sahip yerel halktan müteşekkil iki ana gruptan oluştuğu görülmektedir. Bu iki ana grup arasında, çok az sayıdaki istisnalar hariç tutulursa, geçișlilik bulunmadığı da anlaşılmaktadır. Daha doğru bir ifadeyle idareci sınıf olan askerî aristokrasi, yönetimi kendi tekelinde tutmakta, halkın hiçbir şekilde bu alana girmesine müsaade etmemektedir. Halk ise yönetime karışmamakta, sadece, ziraat ve ticaret gibi işlerle meşgul olarak belirlenen vergileri ödemektedir. Bu kesimden bazıları divanî, adlî ve dinî birtakım görevlerde istihdam edilmekteyse de söz konusu vazifelerin denetimi de yine ümera sınıfinın elindeydi (Lane-Poole, 1901, s. 252-253; Ashtor, 1976, s. 282 vd.; Kopraman, 1992, s. 28, 29; Yiğit, 1991, s. 379, 381).

Şüphesiz, Memlükler'in kendilerine yabancı ve böylesine farklı oldukları bir halkın yaşadığı coğrafyada devlet kurmaları ve hükümranlıklarını ilan etmeleri kolay olmamıştır. Ancak bu noktada bazı şartların onların lehine gelişmesi, hâkimiyetlerini yerleştirmelerine yardımcı olduğu gibi güçlü bir devlet yapısı tesis etmelerine de imkân tanımıştır. Onların lehine gelişen şartların başında, Moğollar ve Haçlılara karşı kazandıkları büyük zaferler gelmektedir. Diğer yandan, Memlükler'in hâkimiyetlerini kabul ettirme ve yerleştirmeleri konusunda, söz konusu savaşlarda kazanılan zaferlerin sağladığı saygınlığın yanı sıra Mısır toplumunun seçkin sınıflarından birini oluşturan ulemanın oynadığı aracı rol de büyük önem taşımaktadır. Nitekim divanî, adlî ve dinî birtakım görevleri de yürüten ulemanın, yerel halkın geri kalanlarına nispetle devlet idaresine daha yakın olmaları hasebiyle, hâkim grup Memlüklerle halk arasında köprü vazifesi görerek önemli bir sosyal ișlev üstlendikleri ifade edilmektedir (Yiğit, 1991, s. 382; a.mlf., 2004, s. 96; Kopraman, 1992, s. 29-30; Kasım, 1983, s. 24; Keleş, 2002, s. 396). ${ }^{3}$ Şüphesiz Memlükler'in ulemaya gösterdikleri teveccühün asıl sebebi, onların taşıdıkları dinî kimlikten dolayı halk tarafından sevilip sayılmalarıdır. Saîd A. Âşûr, halkın ulemaya karşı çok saygılı davrandığını, onlar için "zamanın fakîhi”, "asrın âlimi” vb. övgü dolu sıfatlar kullandığını ifade etmek suretiyle bu duruma işaret etmektedir ( Âşûr, 1992, s. 37). ${ }^{4}$ Dolayısıyla Memlükler'in bu tür vasıfları taşıyan kimselerin itibarından istifade ederek dinî bir meşruiyet kazanma ve böylece siyasî hâkimiyetlerini yerleştirme yolunu kullandıkları anlaşılmaktadır. Nitekim Sultan Baybars'ın Abbâsî hilâfetini Mısır'da yeniden tesis etmesinin as1l nedeni olarak da bu durum gösterilmektedir (Âşûr, 1992, s. 35; Thorau, 1992, s. 113; Yiğit, 1991, s. 159).

Sonuç itibariyle, Memlükler kurdukları güçlü askerî sistem sayesinde yabancı oldukları bir coğrafyada kendilerinden birçok bakımdan farklı olan yerel halkı iki buçuk asırdan fazla yönetmeyi başarmışlardır. $\mathrm{Bu}$ konuda askerî güç ve başarılarının yanı sıra yerel halkın içinden çıkan ulemanın nüfuzundan da istifade etmişlerdir. Bu devletin hükümran olduğu uzun sürenin yaklaşık bir asırdan fazlasını oluşturan Türk Memlükler dönemi, devletin kuruluşunda yaşanan sıkıntılı süreç, idarî teşkilatın oluşturulması ve hâkimiyetin yerleştirilmesi gibi önemli gelişmeleri barındırmaktadır. Nitekim Sultan Baybars'ın bahsi geçen dört başkadı tayini uygulaması da bu süreçte gerçekleşmiştir. Devletin gerçek kurucusu kabul edilen ve hâl tercümesinden bahseden eserlerde zeki, ileri görüşlü, dindar ve kararlı bir kişi olarak tanıtılan Baybars'ın mevcut toplumsal yapıya göre düzenlemeler yaptığını düşünmek kanaatimizce isabetli olur.

Sultan Baybars, devletin temellerini sağlamlaştırırken kendilerine tahtı gasp eden zorba köleler olarak bakan halkla ilişkilerde ulemanın meşrulaştırıcı aracılığına başvurmuş olmalıdır. Bu ulemanın önemli bir kısmı ile halkın ekseriyeti de Şâfiî mezhebine mensuptur (Makrîzî, ts., 2, s. 343; Nielsen, 1984, s. 171 172; Tomar, 2004, s. 575; Tarsûsî, 1992, s. 14 vd.). Dolayısıyla mezhebî bakımdan mevcut toplumsal yapı göz önüne alınmalıdır. Dahası Şâfiî ulemanın idareye karşı tutumu halkı harekete geçirme veya etkileme açısından da önemlidir. Nitekim Sultan Baybars mevcut duruma riayet ederek dört başkadı uygulamasında Şâfiî mezhebinin ayrıcalıklı konumunu muhafaza etmiş̧, vakıflar, yetim mallarının idaresi, mezalim oturumlarında protokol önceliği vb. konulardaki imtiyazlarına dokunmamıştır. Esasen bahsi geçen özellikleri haiz, idare üzerinde halkın desteğiyle önemli bir nüfuza sahip olan Şâfîi kadı ve âlimlerin bu imtiyazlarını almak en azından ilk dönemde pek mümkün de gözükmemektedir. Nitekim bu

\footnotetext{
${ }^{3} \mathrm{Bu}$ görüşün aksine, özellikle Çerkez Memlükler döneminde, halkın ulemaya karşı tepkili davranmaya başladığı hatta bu tutumunu “Arab'ın adaleti yerine Türk'ün adaletsizliğini” tercih edecek kadar ileri götürdüğü de ileri sürülmektedir. Haarmann, 1988, s. 71.

${ }^{4}$ Âşûr'un görüşlerine paralel olarak, ulemanın toplum üzerindeki etkinliği konusunda Ira Lapidus'un değerlendirmeleri için bkz. Lapidus, 1987, s. 181-194.
} 
dönemde kadılık vazifesini deruhte etmiş bazı Şâfî̂ âlimlerle sultanların münasebetlerine ve Şâfiîler'in dört başkadı uygulaması hususundaki rüya motifine dayalı ağır tenkitlerine dair Memlük kaynaklarındaki rivayetler bu konuda idarecilerin hassas davranma sebeplerini ortaya koyar mahiyettedir. Mesela meşhur Şâfiî kadısı İzzeddin b. Abdüsselam'ın (ö. 660/1262) Eyyûbîler döneminden beri devam eden halk nezdindeki itibarı ve yönetimdeki nüfuzunu Memlük idarecileri de kabullenmek zorunda kalmışlardır. Nitekim onun şer'î usule göre azat edilmediği gerekçesiyle Sultan Baybars'a biat etmemesi, daha sonra diğer bazı emîrlerin hür oldukları ispat edilmediği gerekçesiyle bunların yeniden satılması ve elde edilen gelirin Allah yolunda harcanması gerektiğine dair fetva yayınlaması sultanla ilişkilerini bozmuş, bunun üzerine İzzeddin b. Abdüsselam Dımaşk'a dönmeye karar vermiş̧ir. Onun başkentten ayrılmasının Sultan Baybars'ın tahtını tehlikeye düşüreceği uyarısı üzerine sultan bizzat bu kadının yanına gidip gönlünü almak ve fetvasının gereğini yerine getirmek zorunda kalmıştır (Sübkî, 1964, 8, s. 217-218; Apaydın, 1999, s. 285; Kütübî, 1973-1974, 2, s. 352). Taceddin es-Sübkî de onun vefatından sonra Sultan Baybars'ın çok rahatladığını, cenazedeki kalabalığa bakarak "Bugün saltanatım güçlendi, şayet o yaşasaydı ve bu insanlara bana karşı isyan etmelerini söyleseydi tahtım kesinlikle elimden çıkardı" şeklinde ifadeler kullandığını ileri sürer (Sübkî, 1964, 8, s. 215). Yine İzzeddin b. Abdüsselam'ın vefat etmeden önce başkadılığa Taceddin b. bintü'l-Eazz'in getirilmesi, vezirliğe de Bahaeddin b. Hinnâ'nın (ö. 677/1279) tayin edilmesi şeklinde Baybars'a yaptığ tavsiyeler de dikkate alınmış ve yerine getirilmiştir (Nüveyrî, 1990, s. 76; Yûnînî, 1954-1961, 2, s. 174; İbn Kesîr, ts., 13, s. 249). Taceddin b. bintü'l-Eazz da selefi gibi Şafiî etkinliğini devam ettirmiş, bazı icraatlarda engelleyici rol oynamıştır. Mesela Ezher Camii'nin tekrar açılması ve burada hutbe okunması konusunda aleyhte tavır almış, Hanefí ümerayı engellemeye çalışmıştır. Ancak Emîr İzzeddin Aydemir el-Hıllî (ö. 667/1269) bu camii yeniden ibadete açmak için çok uğraşmış, cami ve civarında hayır eserleri vücuda getirmiş, burada hutbe okunması için fetva çıkarttırmış ve neticede muvaffak olarak camiin açılışını büyük bir törenle ve çok sayıda emîrin iştirakiyle gerçekleştirmiştir (665/1267) (İbn Abdüzzâhir, 1976, s. 277). Ne var ki bu camiin açılması için izin veren ve ciddi yardımlarda bulunan Sultan Baybars (İbn Abdüzzâhir, 1976, s. 277), Taceddin b. bintü'l-Eazz'in tepkisinden çekindiği için açılışa katılmamıştır. Neredeyse bütün devlet erkânı açlışta hazır bulunurken sadece sultan ve Taceddin b. bintü'l-Eazz bu merasime iştirak etmemişlerdir (Makrîzî, 1956-1973, 1/2, s. 557; Lahmuddin, 2004, s. 112; Nielsen, 1984, s.173). Şâfî̂ başkadının etkinliği ve Şâfîiler'in hâkimiyeti o kadar fazladır ki, bu camiin açılması için gayret gösteren kudretli emîrlerden Bedreddin Bilik (ö. 676/1277), kendisi Hanefî olmasına rağmen camide ders vermek üzere bir Şâfiî’yi tayin etmek zorunda kalmıştır (İbn Abdüzzâhir, 1976, s. 277). ${ }^{5}$

Taceddin es-Sübkî’nin dört başkadı uygulamasına yönelik tenkitleri de halk üzerinde büyük etkisi bulunan Şâfî̂ ulemanın meseleye bakışını ve Memlük sultanlarının ne tür bir baskı altında bulunduklarını ortaya koyar mahiyettedir. Sübkî, Mısır ve Şam'da Şâfiî mezhebine mensup olmayan bir kadıyı tayin eden sultanların uzun ömürlü olmadıklarını ve memleketlerinin harap olduğunu ileri sürmektedir. Ona göre Mısır'da Şâfiî olmayan sultanlar da uzun süre iktidarda kalamamış ve katledilmiş̧lerdir. Nitekim el-Melikü'l-Muzaffer Seyfeddin Kutuz (657-658/1259-1260) Hanefî olduğundan tahtta uzun süre kalamamış ve öldürülmüştür. Baybars da kendisi Şâfiî olmasına rağmen Şâfiî başkadıya ortaklar tayin etmesi sebebiyle saltanatın kendi neslinden devam etmemesiyle cezalandırılmıştır. Sübkî’nin iddialarına göre ölümünden kısa süre önce Sultan Baybars rüyasında İmam Şâfiî̀'yi görmüş ve bu icraatı sebebiyle azarlanmış, onun "Mezhebime ihanet mi ediyorsun, bu beldeler senin mi yoksa benim mi, seni ve zürriyetini kıyamete kadar saltanattan azlediyorum" şeklindeki ifadelerine muhatap olmuştur. Sübkî, bu rüyadan kısa süre sonra Baybars'ın vefat ettiğini, saltanatın çocuklarında kalmadığını, kendi döneminde Baybars ailesinin fakir bir hayat sürdüğünü de eklemektedir. Sübkî iddialarını daha da ileri götürmüş, Baybars'ın vefatından sonra salih bir kiş̧inin rüyasına girdiğini, üç şeyden dolayı azaba maruz bırakıldığını, bunlardan birinin de Şâfiî dışındaki mezheplerden başkadı ataması olduğunu söylemiştir. Sübkî, Baybars'in çocuklarından tahtı alan el-Melikü'l-Mansûr Seyfeddin Kalavun'un (678-689/1279-1290) Şâfiîler'e saygıs1 sayesinde saltanatın kendi sülalesinde uzun süre kalmasını sağladığını da ileri sürmektedir (Sübkî, 1964, 8, s. 320-321). Bu konuda Sübkî’nin, bazı Şâfiî âlimlerden naklettiği rivayetlerin de oldukça ilginç ve ağır ifadeler içerdiğini belirtmeliyiz.

\footnotetext{
${ }^{5}$ Lahmuddin, muhtemelen dikkatinden kaçtığı için Hanefî olan ve camide müderris tayin eden emîrin Aydemir el-H1llî olduğunu belirtmektedir (Lahmuddin, 2004, s. 112).
} 
Memlük toplumunun zikredilen yapısı, hâkim Şâfî̂ ulemanın meseleye bakışı ve halk üzerindeki etkinliği birlikte değerlendirildiğinde ve yukarıdaki rivayetler göz önüne alındığında Memlük sultan ve emîrlerinin ne kadar hassas bir zeminde hareket ettiği anlaşılmaktadır. Bu noktada bazı sultanların mezhebî mensubiyetleriyle alakalı Sübkî rivayetlerinde yer alan bilgilere de kısaca temas etmeliyiz. $\mathrm{Bu}$ rivayetlerde, açıkça Kutuz'un Hanefî, Baybars'ın Şâfiî olduğu, zımnen Kalavun ve zürriyetinin de Şâfiî mezhebine intisap ettikleri ileri sürülmektedir. Bizim tespit edebildiğimiz kadarıla Memlükler dönemi biyografi kaynaklarında sultanların mezhebî mensubiyetlerine temas edilmemektedir. Hatta bizim kanaatimize göre bu özellikle yapılmaktadır. Çoğu zaman, Hanefî âlimi olanlar hariç tutulursa ümeranın mensup olduğu mezheplere de işaret edilmemektedir. Dahası Hanefî tabakatlarında sultanların ve Hanefî olduğu bilinen ve bizim ileride temas edeceğimiz emîrlerin dahi hâl tercümeleri yer almaz. Dolayısıyla Sübkî’nin bu husustaki nakilleri mezhebî taassup çerçevesinde değerlendirilmeli ve ihtiyatla karşılanmalıdır.

Sübkî’nin bu iddialarını nakzeden ve konumuzla alakalı doğrudan delil teşkil eden rivayetlerin bulunduğunu da belirtmeliyiz. Nitekim Sübkî tarafindan Şâfiî mezhebine mensup olduğu ileri sürülen Sultan Baybars, kendi inşa ettirdiği medresesinde hem Şâfiî hem de Hanefî mezheplerinden birer müderris tayin etmiştir (662/1263) (İbn Abdüzzâhir, 1974, s.184; Nüveyrî, 1990, s. 94; Nielsen, 2004, s. 174). Daha önce de ifade ettiğimiz gibi halk ve ulema arasında hâkim mezhep Şâfiîlik olmasına rağmen Baybars, Hanefîliği Şâfiîliğe denk kabul etmiş gözükmektedir. Sultanın ertesi yıl gerçekleştirdiği dört başkadı atamasından hemen sonra bir Hanefî kadıyı Kahire hatipliğine tayin etmiş olması da (Makrîzî, 1956-1973, 1/2, s. 540; Nielsen, 2004, s. 174) bu bağlamda zikredilebilir. Yine aynı sultanın 668 (1270) senesinde kendi adıyla anılan ve Hüseyniyye semtinde inşa ettirdiği camiin hatipliği vazifesini Hanefî mezhebi mensuplarına tahsis etmiş olması da (Makrîzî, 1956-1973, 1/2, s. 588; ts., 2, s. 300; Nielsen, 2004, s. 174) Sübkî’nin iddiasını nakzeder mahiyettedir.

Kaynaklarda Sultan Baybars'ın Hanefîliğe meylini gösteren daha pek çok örneğe rastlamak mümkündür. Mesela onun çıktığı bütün askerî seferler sırasında yanına Hanefî başkadısı Sadreddin Süleyman'1 (ö. 677/1279) alması (İbnü'l-Furât, 1942, s. 119-120; Nielsen, 2004, s. 175), Hac vazifesini ifa ederken yine bu kadıyı yanında götürmesi ve onun fetvalarıyla hareket etmesi (İbn Abdüzzâhir, 1976, s. 355) bu örnekler arasında zikredilmelidir. Son olarak Sultan Baybars'ın, oğlu el-Melikü's-Saîd Berke'nin (676678/1277-1280) nikâhını da aynı kadının kıyması (İbn Şeddâd, 1983, s. 134-135) Nielsen'in ifadesiyle Baybars'in duygusal olarak Hanefîliğe bağlılığını (Nielsen, 2004, 175) ortaya koyan bir örnek olarak dikkati çeker.

Sultan Baybars'ın dört başkadı tayini uygulaması, onun ve Türk ümeranın Hanefîliğe meyli kadar Şâfiîlik ve Şâfiîlerin nüfuzunu azaltma çabası çerçevesinde de değerlendirilmelidir. Daha önce ifade edildiği gibi Eyyûbîler dönemiyle birlikte büyük bir etkinlik sahibi olan Şâfiî ulema İzzeddin b. Abdüsselam örneğinde görüldüğü üzere yönetimin birçok idarî tasarrufunda engelleyici rol oynamaktaydı. Kuruluş döneminde teşkilatlanma faaliyeti tamamlandıktan ve Moğollarla Haçlılara karşı büyük başarılar kazanıldıktan sonra İslâm dünyası ve Memlük toplumu nezdinde ihtiyaç duyulan siyasîdinî meşruiyet temin edilmişti. Dolayısıyla Sultan Baybars bundan sonraki süreçte Şâfîi ulemanın etkinliğini azaltmak amacıyla bahsi geçen uygulamayı başlatmış olmalıdır. Nielsen, Baybars'ın Şâfiî ulemanın etkinliğini azaltmak istemesinde onların geleneksel olarak Eyyûbîler ile yakın bağlantılarının da rolü olduğunu ileri sürmektedir (Nielsen, 2004, s. 172). Sonuçta dört başkadı tayininde bu son etkenler de etkili olmakla birlikte, daha önce zikrettiğimiz örnek hadiselerde görüldügü gibi Baybars ve Türk emîrlerin Hanefîliğe meylinin önemli bir faktör olduğunu söylemek mümkündür. ${ }^{6}$

\section{Baybars Sonrası Dönemde Sultanlar ve Ümeranın Hanefîliğe Meyli}

Sultan Baybars döneminden sonraki gelişmelere bakıldığında da bazı sultanlar ve emîrlerin Hanefíliğe meyli olduğunu gösteren örnek hadiseler tespit edilmektedir. Mesela Sübkî tarafından Şâfîi oldukları ileri sürülen Kalavun hanedanından el-Melikü'n-Nâsır Muhammed b. Kalavun'un (birinci saltanatı: 693694/1293-1294, ikinci saltanatı: 698-709/1299-1309, üçüncü saltanatı: 709-741/1309-1341), Hanefí başkadısı Şemseddin el-Harîrî’ye (ö. 728/1328) çok hürmet ettiği ve yakınlarına ondan çekindiği kadar

\footnotetext{
${ }^{6}$ Farklı değerlendirmeler için bkz. Rapoport, 2003, s. 211 vd.
} 
hiç kimseden çekinmediğini söylediği aktarılmaktadır (Âşûr, 1992, s. 38). Sultanın bu başkadıya olan hürmeti ve ondan çekinmesinin sebebi Şemseddin el-Harîr̂̀’nin görevi srrasındaki tavizsiz ve cesur tutumudur. Nitekim el-Melikü'n-Nâsır Muhammed b. Kalavun'un, Sultan Baybars'ın aile vakfına ait arazinin bir kısmında tasarrufta bulunabilmek için ondan fetva istediği ancak başkadının buna cevaz vermediği belirtilmekte, bu sebeple aralarının açıldığı, sonuçta başkadının görevden alındığ kaydedilmektedir. Ne var ki bu fetvayı verme vaadiyle onun yerine tayin edilen bir başka Hanefî kadısı da kısa süre sonra vefat etmiş, bu gelişme Şemseddin el-Harîr̂̀'nin kerametine hamledilmiş ve sultan onu görevine iade etmiştir (Makrîzî, 1956-1973, 2/1, s. 173, 174). Aynı kadının Sultan Muhammed b. Kalavun'un kızının nikâhını kıymak için seçilmiş olması da (Makrîzî, 1956-1973, 2/1, s. 237) burada zikredilmesi gereken örnekler arasındadır. Yine bu kadının vefat etmeden önce yerine tayin edilmek üzere bir Hanefî âlimi tavsiye ettiği ve sultanın da bu tavsiyeye uyduğu nakledilmektedir (İbn Kesîr, ts. 14, s.147). Ancak aynı sultanın mezhebî taassup içerisindeki bazı Hanefî âlimlerden hoşlanmadı̆̆ı ve onların Türk ümera ile yakın münasebetler kurmasını yasakladığı da belirtilmelidir (Makrîzî, 1956-1973, $2 / 3$, s.813). Esasen bu hadise de ümera ve Memlükler arasında Hanefîliğin yaygın olarak benimsendiğini ortaya koyar mahiyettedir.

Türk Memlükler döneminde sultanların Hanefîliğe olan meylini gösteren örnekler arasında Hanefîliğin başkadı protokolünde mertebe bakımından ikinci sıraya getirilmesi de zikredilmelidir. Nitekim mezalim oturumlarında protokolün Hanefîler lehine kısmen değiştirilmesi buna örnektir. İlk zamanlarda bu oturumlarda sultanın sağ tarafında başta Şâfiî başkadısı olmak üzere kâdilkudâtlar sıralanmaktaydı (İbn Fazlullah el-Ömerî, 1985, s. 36). Memlükler döneminin meşhur ansiklopedistlerinden Kalkaşendî’nin (ö. 821/1418) verdiği bilgiye göre bu sıralama daha sonra değişmiş, Hanefî başkadısı sultanın sol yanına ve ilk sıraya yerleştirilmiştir (Kalkaşendî, 1963, 4, s. 45; Nielsen, 1985, s. 56, 57). Yine önceleri özel kıyafet giyme ayrıcalığına sadece Şâfiî başkadısı sahipken (İbn Fazlullah el-Ömerî, 1985, s. 51), Kalkaşendî’nin zamanında Hanefî̀ başkadılarına da aynı imtiyaz tanınmıştır (Kalkaşendî, 1963, 4, s. 42). Çerkez Memlükler döneminde (784-923/1382-1517) yaşamış olan meşhur emîr ve âlimlerden İbn Şahin ezZâhirî de (ö. 873/1468) başkadıların protokol sıralamasında Hanefî kâdilkudâtının ikinci sırada yer aldığını belirtmek suretiyle (İbn Şahin ez-Zâhirî, 1894, s. 92) bu mezhebin konumunu sonraki dönemlerde de muhafaza ettiğini ortaya koymaktadır.

Çerkez Memlükler dönemi sultanlarından bazılarının Hanefî ulemaya gösterdiği saygıya dair örnekler bu dönemde de hükümdarların Hanefîliğe meyilli olduğu intibaını vermektedir. Mesela bu dönemin meşhur sultanlarından el-Melikü'l-Müeyyed Şeyh el-Mahmûdî'nin (815-824/1412-1421) meşhur tarihçi ve Hanefî kadısı Aynî’yi (ö. 855/1451), Müeyyediyye Medresesi'nin açılışından hemen sonra hadis hocalığı vazifesine tayin ettiği, daha sonra onu yakınları arasına aldığı ve görüşlerine başvurduğu nakledilmektedir. Sultan Şeyh el-Mahmûdî’nin çok güvendiği ve itibar ettiği Aynî’yi elçilik vazifesinde de istihdam ettiği belirtilmektedir (Sehâvî, ts., 10, s. 132).

Aynî’nin el-Melikü'l-Eşref Barsbay (825-841/1422-1438) ile yakın ilişkileri de meşhurdur. Barsbay'ın "Aynî olmasaydı, biz Müslüman olamazdık" dediği ve dinî konularda onun görüşlerine göre hareket ettiği, daha önce Hanefîler'in atanmadığı bazı önemli görevlere onu tayin ettiği nakledilir (İbn Tağriberdî, 1984-2006, 11, s. 195; Sehâvî, ts.,10, s. 132). Bazı Memlük tarihçileri onun Sultan Barsbay'la olan münasebetlerinin kendisine ayrıcalıklı bir mevki sağladığını ifade etmekte, sultanla geceleri bir araya gelerek tarih sohbetleri yaptığını, Arapça tarih eserlerini Türkçe'ye çevirerek sultana okuduğunu da bildirmektedirler (Makrîzî, 1956-1973, 4/2, s. 698; İbn Hacer, 1998a, 3, s. 350, 365). Yine onun Sultan Barsbay'ın nedîmleri arasında bulunduğu, sultana tavsiyeleriyle yol gösterdiği de vurgulanmaktadır (İbn Tağriberdî, 1972, s. 111).

Çerkez Memlükler dönemi sultanlarının Hanefîler'e rağbetini gösteren ilginç bir rivayeti daha naklederek bu konuyu kapatmak istiyoruz. Buna göre, 866 (1462) senesinde Nil nehri beklenen vakitte yükselmemiştir. Sultan el-Melikü’z-Zâhir Hoşkadem (865-872/1461-1467) bu konuda görüşünü almak üzere, Hanefî kadı ve âlimlerinden birine haber göndermiş, söz konusu kadı da Mısır'daki Abbâsî ailesinin çocuklar dâhil tamamının Nil nehrinden bir kaba doldurulan suyu ağızlarına almalarını, daha sonra aynı kaba tükürmelerini ve bu suyun da Nil'in ölçümünün yapıldığı Mikyâs'a dökülmesini tavsiye etmiştir. Sultan da bu tavsiye uyarınca söylenenlerin yapılmasını emretmiş, bu yapıldığında da, hadiseyi nakleden tarihçinin ifadesiyle Nil nehri hemen yükselmeye başlamıştır (İbn İyâs, 1982-1984, 2, s. 395). 
Memlükler döneminde emîrlerin Hanefîliğe rağbeti ve meyli konusundaki örneklere gelince bunların başında meşhur emîr, devlet adamı ve tarihçi Baybars el-Mansûrî (ö. 725/1325) gelmektedir. Baybars elMansûrî, el-Melikü'l-Mansûr Seyfeddin Kalavun'un memlüklerinden olup hiyerarşide sultandan sonra gelen saltanat nâibliği başta olmak üzere çeşitli üst düzey vazifeleri yürütmüştür. Bu büyük emîrin, devlet adamlığ ve tarihçiliği kadar Hanefî mezhebine olan bağlılığ da öne çıkmaktadır. Dönemin tarih eserlerinde yer alan ona dair biyografik kayitlarda Hanefî mezhebine mensup olduğu, bu mezhep fikhında fetva ve ders verme konusunda icazet alacak ölçüde zengin bir müktesebatının bulunduğu nakledilmektedir. Onun Kahire'de "el-Medresetü'd-Devâdâriyye" adıyla bilinen bir medrese inşa ettirdiği ve burada Hanefî fikhı okutturmak için ders koydurduğu kaydedilmektedir (Makrîzî, 1991, 2, s. 533). Bu noktada Baybars el-Mansûrî’nin Sultan Muhammed Kalavun'dan büyük sayg1 gördügü ve sultanın onu görünce ayağa kalktığı ve yanına oturttuğu da (İbn Tağriberdî, 3, s. 478) belirtilmelidir.

Ümeranın Hanefî ilgisine dair en dikkat çekici örnek şüphesiz Türk Memlükler döneminin en kudretli emîrleri arasında kabul edilen Yelboğa el-Ömerî (ö. 768/1366) ile alakalı kayıtlardır. Dönemin tarihçileri tarafından mutaassıp bir Hanefî olarak tanıtılan Yelboğa'nın, yapmaya çalıştığı ancak kısmen başarabildiği değişikliklerden biri devlet idaresinin adlî-dinî alanında görev yapan dört mezhebin başkadılarının hiyerarşisinde Hanefîler'i en üst makama çıkarma yolundaki gayretleridir. Hanefîliğe intisap eden diğer mezhep müntesiplerine bolca ihsanda bulunduğu ve aylık maaş bağlattığı rivayet edilmekte, son zamanlarında, önceki uygulamanın aksine protokolde Hanefî baş kadılarını, Şâfiî refiklerinin önüne geçirmeye çalıştığı ancak bunu başaramadığı belirtilmektedir (İbn Hacer, 1997, 1998b, 4, s. 271; Sehâvî, 1995, 1, s. 155; Abdülbâsit el-Malatî, 2002, 1, s. 392). Ancak Hanefî kadılarına bazı imtiyazlar sağlamakta kısmî bir başarı sağladığı da anlaşılmaktadır. Nitekim kaynaklarda onun idareye bütünüyle hâkim olduğu sürece ${ }^{7}$ tesadüf eden 765 (1364) senesinde dârüladl ${ }^{8}$ müftülüğü (iftâü dâri'l-adl) $)^{9}$ görevine ilk defa bir Hanefî kadısının getirildiğinden bahsedilmektedir (Makrîzî, 1956-1973, 3/1, s. 92; Abdülbâsit el-Malatî, 2002, 1, s. 360; krş. Sehâvî, 1995, 1, s. 138). Her ne kadar kaynaklarda bu hususta Yelboğa'nın bir müdahalesinden bahsedilmese de, onun idaredeki mutlak hâkimiyeti ve Hanefî taassubu göz önüne alındığında söz konusu tayinde rolünün olması kuvvetli bir ihtimaldir.

Yelboğa'nın bu türden faaliyetleri dönemin özellikle Şâfiî olanlar başta olmak üzere bazı tarihçileri tarafindan rüya motifleri içerisinde ilginç rivayetlere konu edilmiştir. Nitekim bazı kaynaklarda, Yelboğa'nın Hanefî başkadılarını öne çıkarmaya çalışması ve Şâfiî mezhebine mensup olanlara baskıda bulunarak kendi mezhebine girmek için teşvik etmesi gibi faaliyetleri nedeniyle İmam Şâfiî’nin manevî gazabına uğradığı ileri sürülür. Buna göre Şâfiî âlimler İmam Şâfiî’yi rüyalarında görmüşler, İmam Şâfiî onlara "Kebş’i yıkın" demiştir. Bu rüyalardan kısa süre sonra Yelboğa öldürülmüss, evinin bulunduğu Kebş denilen yer de tahrip edilmiştir. Bir daha burada kimse oturmamış, burası yıkıntı halinde kalmışıır (el-Irâkî, 1989, 1, s. 216; Makrîzî, 1995, 1, s. 130; Sehâvî, 1995, 1, s. 155).

Ümera arasındaki Hanefî ilgisine dair son örnek olarak meşhur tarihçi ve devlet adamı İbn Dokmak’ı (ö. 809/1407) vermek istiyoruz. Meşhur bir emîrin soyundan gelen İbn Dokmak, bir asker olarak yetiştirilmiş ancak daha sonra ilme olan merakı sebebiyle fikıh, edebiyat, tarih gibi alanlarda tahsil yapmaya başlamıştır. İlmî çalışmalarına devam eden İbn Dokmak bir süre valilik de yapmıştır. Hanefîliğe düşkünlüğü ile de tanınan İbn Dokmak bu mezhebe dair eserler telif etmiştir. Onun Hanefî mezhebine dair telif ettiği tabakatta bazı Şâfiî âlimlere dil uzattığı ileri sürülmüş, bu sebeple dönemin Şâfiî fakihleri tarafından şikâyet edilerek muhakeme edilmiştir. Tutuklanarak ve başı açılıp aşağılanarak hapse atılmıştır. Makrîzî'nin ifadesiyle Allah'ın yardımı olmasa Şâfiîler onu idam ettireceklerdir. Sonuçta suçsuzluğu anlaşılan İbn Dokmak serbest bırakılmıştır. Makrîzî, onun isnad edilen suçu

\footnotetext{
${ }^{7}$ Yelboğa'nın idareye hâkim oluşu ve faaliyetleri hakkında bkz. Ayaz, 2007, s. 81-100.

${ }^{8}$ Dârüladl, mezalim oturumlarının gerçekleştirildiği adliye binasına verilen isimdir. Tarihçilerin çoğu tarafindan ilk Memlük sultanı kabul edilen el-Melikü'l-Muiz İzzeddin Aybek et-Türkmânî (648-655/1250-1257) Kahire'deki Sâlihiyye Medresesi'nde mezalim divanı tertip ettirerek burayı dârüladl haline getirmiştir. el-Melikü’z-Zâhir Baybars da söz konusu divan için toplantılar yapmak üzere dârüladl adlı bir bina inşa ettirmiştir. el-Melikü'n-Nâsır Muhammed b. Kalavun ise bir başka bir daire yaptırarak, burayı dârüladl haline getirmiş ve haftada iki defa Pazartesi ve Perşembe günleri mezalim divanı akdetmiştir. Çerkez Memlükler döneminde ise binalar ve toplantı günleri değişmekle birlikte toplantılar devam ettirilmiştir. Memlükler dönemindeki dârüladl binaları ve işlevleri hakkında bilgi için bkz. Makrîzî, ts., 2, s. 308; Nielsen, 1984, s. 51 vd.

${ }^{9}$ Dârüladl müftülüğ̈̈, Memlükler dönemindeki önemli adlî-dinî vazifelerdendir. Her mezhebe ait birer müftü bulunur ve bunlar dârüladldeki mezalim duruşmalarında kazaskerin altında otururlar, Şer‘̂̂ meselelerde fetva verirlerdi. Dârüladl müftülüğü hakkında daha geniş bilgi için bkz. Kalkaşendî, 1963, 4, s. 36, 45; Nielsen, 1984, s. 91-92; Yiğit, 1991, s. 202.
} 
işlemesinin mümkün olmadığını, yakından tanıdığı İbn Dokmak'ın hiç kimse aleyhine konuşmayan nazik bir insan olduğunu, yanlışlıkla insanları kırarsa gönüllerini almak için çok uğraştığını belirtmektedir (Makrîzî,1995, 1, s.118, 119). Bu hadiseyi aktaran meşhur Şafiî başkadısı ve tarihçi İbn Hacer de (ö. 852/1449), İbn Dokmak'ın İmam Şâfiî aleyhine yazdıkları yüzünden muhakeme edildiğini, yazdığ1 şeylerin başka eserlerden iktibas olduğunu söyleyince dövülmek ve hapsedilmek suretiyle ta 'zirle cezalandırıldığını söyler. İbn Hacer, aslında onun bu cezaya müstehak olmadığını da itiraf eder (İbn Hacer, 1998a, 2, s. 234).

\section{SONUÇ}

Eyyûbîler döneminin sonlarına doğru Mısır'da sayıları oldukça artan memlüklerle birlikte Hanefî mezhebinin bu coğrafyada ciddi bir mevki kazandığı tespit edilmektedir. Makrîzî gibi Mısırlı ve Şâfiî mezhebine mensup tarihçilerin de işaret ettiği gibi Mısır'da hâkim mezhep Şâfiîlik ve halkın ekseriyeti bu mezhebe mensup iken Hanefîliğin ona neredeyse denk bir konumda görülmesi bu tespiti teyit etmektedir. Hanefîliğin bu kadar güç kazanmasında sultan ve emîrlerin bu mezhebe meyli kadar hâkim mezhep konumundaki Şâfiîlik ve Şâfiî ulemanın etkinliğinin azaltılması amacı da rol oynamış gözükmektedir. Özellikle kuruluş döneminde faal olan ve yönetimin tasarruflarında söz sahibi olmak isteyen Şâfiî kadıların bu türden faaliyetleri, Memlük sultanlarının dış siyasetteki başarıları sayesinde ihtiyaç duydukları meşruiyeti elde etmelerinden sonra engellenmeye başlamıştır. Dört başkadı uygulamasının yanı sıra Abbâsî hilafetinin Mısır'da ihdası da Şâfiî başkadılarının tek otorite olmasını engellemeye yönelik icraatlar olarak değerlendirilmektedir.

Memlük Devleti'nin ilk döneminde hâkim unsur olan Türklerin Hanefiliğe meyletmelerinde tarihî süreç içerisinde bu mezhebin Türklerin yaşadığı coğrafyada yaygın kabul görmüş olması elbette önemli etkendir. Ancak bu, Orta Asya ve civarındaki coğrafyadan gayrimüslim köleler olarak getirilen memlüklerin Hanefiliğe meylini izah etmekte yetersiz kalmaktadır. Kanaatimizce, bu devlet zamanında en mükemmel seviyesine ulaşmış olan memlük yetiştirme sistemi bu mezhebin benimsenmesinde önemli rol oynamıştır. Şöyle ki, Memlükler döneminde bahsi geçen sisteme göre çeşitli köle pazarlarından yüksek fiyatlarla satın alınarak Mısır'a getirilen ve ağırlığını Türklerin oluşturduğu memlükler önce dinî bir eğitime tâbi tutulmakta, ardından da askerî eğitiminden geçirilmekteydi. Bu dinî ve askerî eğitim "mukaddemü'l-memâlîki's-sultâniyye" unvanını taşıyan komutanlar gözetiminde gerçekleştirilmekteydi. Muhtemelen çoğu Hanefîliği benimseyen bu komutanların gözetiminde yetişen yeni memlüklere dinî eğitim verilirken Hanefî mezhebine göre tedrisat yapılmaktadır. Kendileri de bu eğitimden geçen birçok Memlük sultanının Hanefî kadılarıyla yakın ilişkileri, nikâh merasimi, hac ifası gibi faaliyetlerinde onları tercih etmeleri, yaptırdıkları cami, medrese gibi hayır eserlerinde yine onları görevlendirmeleri kanaatimizi desteklemektedir. Yine birçok Memlük emîrinin Hanefî mezhebine mensup olmaları ve bir kısmının bu konuda aşırıya kaçan tutumları da düşüncemizi teyit eder mahiyettedir. Sultan Muhammed b. Kalavun'un mutaassıp bir Hanefî kadısının Türk ümera ile yakın ilişkiler kurmasından rahatsız olması da emîrlerin bu mezhebe olan meylini ortaya koymaktadır. Bu meyli de bahsi geçen eğitim sürecinin bir yansıması olarak değerlendirdiğimizi ifade etmeliyiz. Ne var ki tıbâk (t. tabaka) adı verilen kışlalardaki dinî eğitimin mahiyeti hakkında kaynaklarımızın bilgi vermediğini de itiraf etmek durumundayı.

Memlük sultanları ve ümeranın Hanefîliğe meyli bu mezhebe mensup kadıların idarenin tasarruflarını kolaylaştırıcı işlev görmesiyle de alakalı olmalıdır. Nitekim meşhur Hanefî başkadısı Necmeddin etTarsûsî (ö. 758/1357), Türk Memlükler döneminde idareciler için kaleme aldığı siyasetname türü eserinde kendi mezhebinin Türkler için daha uygun olduğunu özellikle vurgulamakta, eserinin ekserisinde buna dair örneklere yer vermektedir. Yine Memlükler dönemi kaynaklarında sultanların özellikle bazı vakıflarda tasarrufta bulunmak için fetva arayışlarında talep ettikleri cevazı genellikle Hanefî mezhebi kadılarından alabildiklerine dair bizim bu tebliğde işaret etmediğimiz pek çok rivayet yer almaktadır. Dolayısıyla Memlükler dönemi idarecilerinin Hanefî mezhebine meyilleri değerlendirilirken bu etken de göz ardı edilmemelidir. Bütün bunlarla birlikte bizim buradaki kanaatlerimizin kaynaklar teferruatlı bir şekilde taranarak daha fazla örnek hadiseyle teyit edilmesi gerekir. 
Bilgilendirme / Acknowledgement: Bu makale "IV. Uluslararası Şeyh Şa‘bân-ı Velî -Hanefilik-MâtûridîlikSempozyumu”"na (05-07 Mayıs 2017-Kastamonu) sunulan tebliğin gözden geçirilmiş ve geliştirilmiş hâlidir.

\section{KAYNAKÇA}

Abdülbâsit el-Malatî, Z.B. (2002). Neylü'l-emel fí zeyli'd-düvel. (Nşr. Ömer A. Tedmürî). I-IX. Beyrut: Mektebeti'l-Asriyye.

Apaydın, H. Y.(1999). İbn Abdüsselâm, İzzeddîn. TDV İslam Ansiklopedisi (DİA) içinde (c.19, ss.284287). İstanbul: Diyanet Vakfi Yay.

Ashtor, E. (1976). A social and economic history of the near east in the middle ages. London: Collins.

Âşûr, S.A. (1992). el-Müctema 'u 'l-Misrî fí 'asri selâtîni 'l-memâlîk. Kahire: Dârü'n-Nehdati’l-Arabiyye.

Ayaz, F.Y. (2007). Türk Memlükler döneminin büyük emîrlerinden Yelboğa el-Ömerî (ö. 768/1366) ve idaredeki nüfuzu. Ç.Ü. Sosyal Bilimler Enstitüsü Dergisi, 16(1), 81-100.

Escovitz, J. H. (1982). The establishment of four chief judgeships in the Mamlûk Empire. Journal of the American Oriental Society, 102(3), 529-531.

Haarmann, U. (1988). rather the injustice of the Turks than the righteousness of the Arabs-Changing 'ulamâ' attitudes towards Mamluk rule in the late fifteenth century. Studia Islamica, 68, 61-77.

el-Irâkî, V. (1989). Ez-zeyl 'ale’l-'iber fî haber men 'aber. (Nşr. Salih M. Abbâs). I-III. Beyrut: Müessesetür'r-Risâle.

İbn Abdüzzâhir, E.F. (1976). Er-ravzü'z-zâhir fî sîreti’l-meliki'z-zâhir. (Nşr. Abdülaziz el-Huveytır). Riyad: y.y.

İbn Fazlullah el-Ömerî, Ş. (1985). Mesâlikü'l-ebsâr fî memâliki'l-emsâr: Memâlikü Musr ve'ş-Şâm ve'lHicâz ve'l-Yemen. (Nşr. Eymen Fuâd Seyyid). Kahire: Institut Français d'Archeoloige Orientale.

İbn Hacer. (1997). Ed-dürerü'l-kâmine fí a 'yâni'l-mieti's-sâmine. (Nşr. Abdülvâris Muhammed Ali). IIV. Beyrut: Dârü'l-Kütübi'l-İlmiyye.

İbn Hacer. (1998). İnbâü'l-ğumr bi-ebnâi'l- 'umr . (Nşr. Hasan Habeşî). I-IV. Kahire:y.y.

İbn Hacer. (1998). Zeylü'd-düreri'l-kâmine. (Nşr. Ahmed Ferid el-Mezîdî). Beyrut: Dârü'l-Kütübi'lİlmiyye.

İbn Haldûn. A. B. (2001). Kitâbü'l- 'iber ve dîvânü'l-mübtede ve'l-haber fì eyyâmi'l- 'Arab ve'l- 'Acem ve'l-Berber ve men 'âsarahüm min zevi's-sultâni'l-ekber. (Nşr. Halil Şehhâde). I-VIII. Beyrut: Dâru'l-Fikr.

İbn İyâs, M. A. (1982-1984). Bedâi 'u'z-zühûr fì vekâi ‘'i'd-dühûr. (Nşr. Muhammed Mustafa). I-V. Kahire: el-Heyetü'l-Misriyyetü'l-Âmme.

İbn Kesîr, E.F. (t.y.). el-Bidâye ve'n-nihâye. (Nşr. Ahmed Ebû Mülhim v.dğr.). I-XIV. Beyrut: Dârü'lKütübi'l-İlmiyye.

İbn Şahin ez-Zâhirî, G.H. (1894). Zübdetü keşfi'l-memâlik ve beyâni 't-turuk ve'l-mesâlik. (Nşr. Paul Ravaisse). Paris: el-Matbaatü'l-Cumhûriyye.

İbn Şeddâd, İ.M. (1983). Târîhu'l-meliki'z-zâhir. (Nşr. Ahmed Hutayt). Beyrut: Merkezü't-Tıbâati'lHadîse.

İbn Tağriberdî, E.M. (1984-2006). El-menhelü’s-sâfî ve'l-müstevfî ba 'de'l-vâfî. (Nşr. Muhammed M. Emin-Nebîl Muhammed Abdülaziz). I-XII. Kahire: Matbaatü Dârü'l-Kütüb.

İbn Tağriberdî. E.M. (1972). En-nücûmü'z-zâhire fî mülûki Mısr ve'l-Kâhire. XV. (Nşr. İbrahim Ali Tarhan). Kahire: el-Müessesetü'l-Misriyyeti'l-Âmme. 
İbnü'l-Furât, N. (1942). Târîhu'd-düvel ve'l-mülûk-târîhu ibni'l-Furât. VII. (Nşr. Kostantin Züreyk). Beyrut: American Press.

el-Kalkaşendî, A. A. (1963). Subhu'l-a şấ fì sinâ 'ati 'l-inşâ, I-XV. Kahire: el-Müessesetü'l-Mısriyyeti'lÂmme.

Kasım, A.K. (1983). Dirâsât fî târîhi Mısri 'l-ictimâî. Kahire: Dârü'l-Ma'ârif.

Keleş, B. (2002). Memlûkler döneminde sosyal yapı. Türkler içinde (C.5, ss. 394-398). Ankara: Yeni Türkiye.

Kopraman, K.Y. (1992). Memlûkler döneminde Misır'da sosyal hayat. Doğuştan Günümüze Büyük İslâm Tarihi İçinde. VII. İstanbul: Çăg.

Kutlu, S. (2011). Türkler ve İslâm tasavvuru. İstanbul: İsam Yay.

el-Kütübî, M.Ş. (1973-1974). Fevâtü'l-vefeyât ve’z-zeylü 'aleyhâ. (Nşr. İhsan Abbâs). I-V, Beyrut: Dâru Sâdır.

Lahmuddin, M. A (2004). Sunni 'ulama and the reform of religious offices in medieval Egypt, 637-676 A. H./A. D. 1240-1277. Yayımlanmamış doktora tezi, University of Arkansas, Arkansas.

Lane-Poole, S. (1901). A history of Egypt in the middle ages. London: Methuen\&Co.

Lapidus, I. (1987). Müdünü İslâmiyye fì 'ahdi'l-memâlîk. (Çev. Ali Mâzi). Beyrut: el-Ehliyye.

el-Makrîzî, T. (1995). Dürerü'l- ‘ukûdi'l-ferîde fî terâcimi a'yâni’l-müfíde. (Nşr. Adnan DervişMuhammed el-Mısrî). I-II. Dımaşk: Vizâretü's-Sekâfe.

el-Makrîzî, T. (1957). İğâsetü'l-ümme bi-keş̧fil-gumme. (Nşr. M. Mustafa Ziyade-Cemaleddin eşŞeyyâl). Kahire: Lecnetü't-Te'lîf ve't-Terceme ve'n-Neşr.

el-Makrîzî, T. (t.y.) Kitâbü'l-mevâ 'iz ve'l-i 'tibâr bi-zikri'l-hıtat ve 'l-âsâr. I-II. Beyrut.

el-Makrîzî, T. (1991). Kitâbü’l-mukaffe 'l-kebîr. (Nşr. Muhammed el-Ya 'lâvî). I-VIII. Beyrut: Dârü’lGarbi'l-İslâmî.

el-Makrîzî, T.(1956-1973). Kitâbü's-sülûk li-ma 'rifeti düveli'l-mülûk (Nşr. M. Mustafa Ziyâde-Saîd A. Âşûr). I-XII. Kahire: Lecnetü't-Te'lîf ve’t-Terceme ve'n-Neşr.

Nielsen, J. S. (1984). Sultan al-zâhir Baybars and the appointment of four chief qâdîs 663/1265. Studia Islamica (60), 167-176.

Nielsen, J. S. (1985). Secular justice in an Islamic state: Mazâlim under the Bahrî Mamlûks 662/1264789/1387. New York: Leiden.

en-Nüveyrî, A.A. Nihâyetü'l-ereb fí fünûni 'l-edeb. I-XVIII. Kahire: Matbaatü Dârü'l-Kütüb.

Özen, Ş. (2001). Kâdılkudât. TDV İslam Ansiklopedisi (DİA) içinde (c. 24, ss.77-82). İstanbul: Diyanet Vakfi Yay.

Rapoport, Y. (2003). Legal diversity in the age of taqlîd: The four chief qâdîs under the Mamluks. Islamic Law and Society 10(2), 210-228.

es-Sehâvî, Ș. (t.y). ed-Dav'ü'l-lâmi 'li-ehli 'l-karni 't-tâsi ‘ I-XII. Kahire: Dârü'l-kütübü'l-İslâmî.

es-Sehâvî, Ş. (1995). Vecîzü'l-kelâm fi'z-zeyl 'alâ düveli'l-İslâm. (Nşr. Beşşâr A. Maruf v.dğr.). I-IV. Beyrut: Müessesetü'r-Risâle.

es-Sübkî, T.A. (1964). Tabakâtü'ş-Şâfi 'iyyeti'l-kübrâ. (Nşr. Mahmud Muhammed et-Tanâhî, Abdülfettah Muhammed el-Hulv). I-X. Kahire: Dâru İhyâi'l-Kütübi'l-Arabiyye.

Şık, İ. (2015). Mâturidî inanç sistemi. Ankara: Gece Kitaplığı.

et-Tarsûsî, N.İ. (1992). Tuhfetü't-Türk fimâ yecibü en yu 'mel fi'l-mülk. (Nşr. Rıdvan es-Seyyid). Beyrut: Dâru't-Talia. 
Thorau, P. (1992). The lion of Egypt sultan Baybars I and the near east in the thirteenth century (Çev. P. M. Holt). London, New York: Longman.

Tomar, C. (2004). Misır. TDV İslam Ansiklopedisi (DIA) içinde (c.29, ss.575-577). İstanbul: Diyanet Vakfi Yay.

Yalçın, M.F. (2016). Bahrî Memlükler döneminde Dımaşk kâdılkudâtları (1266-1382), Konya: Aybil Yay.

Yiğit, İ. (2004). Memlükler. TDV İslam Ansiklopedisi (DİA) içinde (c.29, ss.90-97). Ankara: Diyanet Vakfi Yay.

Yiğit, İ. (1991). Siyasi-dini-kültürel-sosyal islâm tarihi: Memlûkler. VII. İstanbul: Kayıhan Yay.

el-Yûnînî, K. (1954-1961). Zeylü mir'âti’z-zamân. I-IV. Haydarâbâd: Dâiretü'l-Maârifi'l-Osmânî.

ez-Zehebî, Ş. (1999). Târîhu'l-İslâm ve vefeyâtü'l-meşâhîr ve'l-a 'lâm: sene 661-670. (Nşr. Ömer A. Tedmûrî). Beyrut: Dâru'l-Kütübi'l-Arabî. 